\title{
On the Nature of 0öcytin, the Fertilising and Cytolysing Substance in Mammalian Blood-Sera.
}

\author{
By \\ T. Brailsford Robertson. \\ (From the Rudolf Spreckel's Physiological Laboratory of the University \\ of California.) \\ Eingegangen am 27, Februar 1913.
}

\section{Previous attempts to characterise the Fertilising Agent.}

In previous articles $\left.{ }^{1}\right) I$ have shown that the agent in ox-serum which brings about the formation of fertilisation-membranes in seaurchin eggs ${ }^{2}$ ) can be isolated in an impure condition by a process consisting, essentially, in precipitation by barium chloride, resolution of this precipitate in dilute acid, removal of the excess of barium by excess of sodium sulphate, and reprecipitation by acetone.

The substance thus prepared, when dissolved in sea-water, readily caused, at very bigh dilutions, the formation of fertilisationmembranes in sea-urchin eggs which had been previously sensitised by 4 minutes immersion in $3 / 8 \mathrm{M}$. $\mathrm{SrCl}_{2}$. It contained, however, a considerable proportion of sodium sulphate which was precipitated by the excess of acetone ( 5 vols. acetone to 1 vol. of solution) employed in the final precipitation. It also contained traces of phosphates. As will be be seen below it is possible to obtain an active preparation which does not contain either of these substances.

This impure preparation yielded an atypical MiLlon's reaction and a positive ACREe-Rosenheim test for proteins. It failed, however, to yield the biuret test or the Xanthoproteic test, failures which,

1) T. Brailsford Robertson, Journ. of Biological Chemistry. Vol. 11. 1912. p. 339; Vol. 12. 1912. p. 163. Arch. f. Entw.-Mech. Bd. 35. 1912. S. 64.

2) J. Loeb, Arch. f. d. ges. Physiol. Bd. 118. 1907. S. 36; Bd. 122.1908. S. 196; Bd. 124. 1908. S. 37; >Die chemische Entwicklungserregung des tierischen Eies. Berlin 1909. S. 185. 
in view of more recent results with the purer product described below, are probably attributable to the large proportion of impurities and small proportion of active substance contained in the preparation. Although this substance caused the formation of fertilisation-membranes in sensitised purpuratus eggs at a dilution of one to half a million it could not be demonstrated to possess any enzymatic action.

\section{The Chemical Properties of a purer Preparation of Oöcytin.}

I have attempted to obtain a purer preparation of the fertilising agent in ox-serum in the following manner:

To four and a half litres of ox-serum, prepared by whipping freshly-drawn ox-blood and then centrifugalising, were added 5 volumes of acetone, and the resultant precipitate was drained and dried until of a cheesy consistency and then passed through a mincing machine and rabbed up into a coarse powder between the hands and further partially dried over sulphuric acid at $36^{\circ} \mathrm{C}$. This powder, which still contained traces of acetone, was suspended in $4 \frac{1}{2}$ litres of $\mathrm{N} / 10 \mathrm{HCl}$ and slowly heated to $\left.65^{\circ} \mathrm{C} .1\right)$. The powder swelled enormously, but did not go into solution. The mixture was filtered through glass wool while hot. The filtrate was a clear pinkish yellow, measured $3900 \mathrm{cc}$. and contained only small quantities of protein. Titrating it against phenolpthalein its acidity was found to be only $0.051 \mathrm{~N}$, indicating that one half of the acid had been bound by the undissolved residue. The acidity was made up to $\mathrm{N} / 10$ by adding 200 cc. of $\mathrm{N} / 1 \mathrm{HCl}$ and the mixture again titrated. The titration this time indicated an acidity of $0.098 \mathrm{~N}$. The mixtare was now exactly neutralised by the addition of $1100 \mathrm{cc}$. of $0.346 \mathrm{~N} \mathrm{Ba}(0 \mathrm{H})_{2}$. A cloud at once appeared which only settled with extreme slowness, consequently the entire volume was centrifuged, causing the pure white precipitate to pack tightly at the bottom of the centrifuge tubes. This precipitate was washed once by suspending it in 200 cc. of $1 \% \mathrm{BaCl}_{2}$ solution and centrifuging again. It was then suspended in $100 \mathrm{cc}$. of $\mathrm{N} / 10 \mathrm{H}_{2} \mathrm{SO}_{4}$ which had previously been heated to $75^{\circ}$. This mixture was allowed to stand at $50^{\circ}$ for three hours and the slightly opalescent supernatant fluid then decanted without disturbing the precipitate of barium sulphate which had settled to the bottom of

1) The fertilising agent is not affected by 24 hours exposure to $65^{\circ} \mathrm{C}$. Cf. J. Loeb, loc. cit., and T. Brailsford Robertson, Arch. f. Entw.-Mech. Bd. 35. 1912. S. 64 . 
the flask. This fluid was then filtered and five volumes of acetone were added to it. A white flocculent precipitate appeared which was collected upon a hardened filter, washed with $100 \mathrm{cc}$. of acetone, dried over sulphuric acid at $36^{\circ} \mathrm{C}$. for 48 hours, and then scraped off the paper and weighed. The substance was thus obtained in the form of a brown powder, the total yield being only 44 milligrams, or 10 milligrams per litre of serum.

The yield of impure substance obtained in previous preparations was no less than 560 milligrams per litre containing 521 milligrams of $\mathrm{Na}_{2} \mathrm{SO}_{4}$. This preparation was free from sulphates, phosphates and barium, hence, as compared with previous preparations, it was of a very high degree of purity. We may conclude that the content of fertilising agent in normal ox-serum lies between 10 and 40 milligrams per litre.

Twenty milligrams of this preparation were rubbed up with $20 \mathrm{ec}$. of filtered sea-water. A small portion appeared to go into solution, yielding a very opalescent fluid, the remainder forming an unstable suspension. This mixture ( 1 part of fertilising agent to 1000 of seawater), was diluted to $1 / 2,1 / 4 \ldots$ etc. by successive additions of seawater. The eggs of a purpuratus female were sensitised by 4 minates immersion in $3 / 8 \mathrm{~m} \mathrm{SrCl}_{2}$ and two drops of a suspension of these eggs were added to 2 cc. portions of each of the solutions thus obtained. At the same time 2 drops of unsensitised eggs of the same female were added to 2 cc. portions of the most concentrated mixture. After one hour spseudo-membranes* which were permeable to sperm had formed upon the unsensitised eggs, while upon the sensitised eggs true membranes had formed in the more dilute mixtures, the dense precipitate which surrounded the eggs in the mixtures containing 1 part-to 16000 or a greater proportion of the substance preventing any view of the periphery of the eggs 1 ). The following were the results obtained in the $1: 32000$ and more dilute mixtares:

\begin{tabular}{c|c|c}
\hline $\begin{array}{c}\text { Dilution of the } \\
\text { substance }\end{array}$ & $\begin{array}{c}\% \text { of membranes formed } \\
\text { after } \text { \& hour }\end{array}$ & $\begin{array}{c}\% \text { cytolysed after } \\
7 \text { hours }\end{array}$ \\
\hline $1: 32000$ & 21 & 10 \\
$1: 64000$ & 25 & 8 \\
$1: 128000$ & 90 & 14 \\
$1: 256000$ & 28 & 10 \\
$1: 512000$ & 2 & 22 (over $80 \%$ \\
& & membranes)
\end{tabular}

1) This was due to the fact that the $\mathrm{SrCl}_{2}$ with which sensitised eggs are impregnated precipitates the substance at their periphery. 
The substance was therefore extremely potent at very high dilutions.

The properties of this substance, in so far as the limited amount of material permitted their determination, were the following:

Solubilities.

Insoluble in hot or cold methyl or ethyl alcohol, ether or benzol.

Soluble in dilute (N/10) acids and alkalies, more so when hot. The solutions are opalescent and the substance is not precipitated by nentralisation nor by boiling in neutral solution. It is precipitated from neutral solutions by chlorides of the alkaline earths.

Colour Reactions.

The Mrllon, Acree-Rosenhem and Xanthoproteic tests for protein were all positive, the last-mentioned very markedly so. The osmic acid test for unsaturated fatty acids and the MoLisch test for carbohydrates were negative.

From these results it appears certain that the membrane-forming agent either is a protein or peptone or else is precipitated by the above method of preparation, together with a protein or peptone.

\section{The Non-digestibility of the Fertilising Agent by Pepsin.}

I find that WITTE's Peptone, dissolved in sea-water, is capable of causing the formation of fertilisation-membranes and, ultimately, the cytolysis of purpuratus eggs sensitised by immersion in $3 / 8 \mathrm{M}$ $\mathrm{SrCl}_{2}$. The following is one of several experiments which yielded similar results:

Twenty milligrams of WiTTE's Peptone were rubbed up in $20 \mathrm{cc}$. of sea-water, forming an opalescent solution containing one part of WITTE's Peptone to 1000 of sea-water. This solution was diluted to $1 / 2,1 / 4$ and so forth by successive additions of sea-water. The eggs of a purpuratus female were sensitised by 2 minutes immersion in $3 / 8 \quad \mathrm{M} \mathrm{SrCl}_{2}$ and two drops of a suspension of the eggs were added to $2 \mathrm{cc}$. portions of each of these dilutions. The following were the results obtained after 25 minutes and after 5 hours respectively: 
After 25 minutes.

\begin{tabular}{|c|c|c|c|c|c|c|c|}
\hline $\begin{array}{c}\text { Dilution of } \\
\text { Wrtre's Peptone }\end{array}$ & \multicolumn{7}{|c|}{ Effect of immersing the eggs in this solution } \\
\hline 1: 1000 & Preci & $\mathrm{s}$ & oundi & ach & $\mathrm{n}$ & mer & Ines \\
\hline 1: $\quad 2000$ & Bliste & nd & ompl & mem & & & \\
\hline 1: 4000 & $10 \%$ & bra & , som & omp & the & the & mplete \\
\hline 1: 8000 & $26 \%$ & - & - & - & - & - & - \\
\hline $1: 16000$ & $28 \%$ & - & - & - & - & - & - \\
\hline 1: 32000 & $30 \%$ & - & - & - & - & - & - \\
\hline 1: 64000 & $12 \%$ & - & - & - & - & - & - \\
\hline $1: 128000$ & $4 \%$ & - & - & - & - & - & - \\
\hline $1: 256000$ & $0 \%$ & - & comp & or $\mathrm{i}$ & $\mathrm{mp}$ & & \\
\hline $1: 512000$ & $0 \%$ & - & . & - & - & & \\
\hline Sea-water & $0 \%$ & - & - & - & - & & \\
\hline
\end{tabular}

After 5 hours.

\begin{tabular}{|c|c|c|c|c|c|c|}
\hline $\begin{array}{c}\text { Dilution of } \\
\text { Wirte's Peptone }\end{array}$ & \multicolumn{6}{|c|}{ Effect of immersing the eggs in this solution } \\
\hline 1: 1000 & \multicolumn{6}{|c|}{$16 \%$ cloudy membranes, $42 \%$ cytolysed } \\
\hline 1: $\quad 2000$ & \multicolumn{6}{|c|}{$38 \%$ complete hyaline membranes, $20 \%$ cytolysed } \\
\hline 1: 4000 & $10 \%$ & - & - & - & $10 \%$ & - \\
\hline 1: 8000 & $20 \%$ & - & - & - & $14 \%$ & - \\
\hline $1: 16000$ & $32 \%$ & - & - & - & $8 \%$ & - \\
\hline $1: 32000$ & $16 \%$ & - & - & - & $0 \%$ & - \\
\hline 1: 64000 & $4 \%$ & - & - & - & $0 \%$ & - \\
\hline $1: 128000$ & $5 \%$ & - & - & - & $0 \%$ & - \\
\hline $1: 256000$ & $0 \%$ & - & - & - & $0 \%$ & - \\
\hline $1: 512000$ & $0 \%$ & - & - & - & $0 \%$ & - \\
\hline Sea-water & $0 \%$ & - & - & - & $0 \%$ & - \\
\hline
\end{tabular}

Now WitTe's Peptone is understood to be prepared from fibrin by digestion with pepsin 1). Whatever may be the nature of the material submitted to digestion, however, it is clear that the membraneforming agent is not completely digested. The membrane-forming substance, therefore, is digested either with difficulty or not all by pepsin. It does not follow, of course, that it is a peptone.

\section{The Non-lipoid Character of the Membrane-forming Agent.}

With a view to obtaining further information concerning the nature of the active substance $I$ have studied the influence of admixtures of Lecithin and Cholesterin upon the membrane-forming

1) W. Kühne und R. H. Chittenden, Zeitschr. f. Biol. Bd. 20. 1884. S. 11. 
action of rabbit-serum. The lecithin was prepared in the following manner:

The yolks of eggs were washed free from adherent whites, mixed with an equal volume of $10 \% \mathrm{NaCl}$ solution and the mixture extracted with twice its volume of ether. The ether extract was evaporated to one-third its volume and the lecithin precipitated by the addition of five volumes of acetone, washed in acetone, drained nearly dry upon a hardened filter, then scraped off the filter into a porcelain dish and dried over $\mathrm{H}_{2} \mathrm{SO}_{4}$ for several weeks. Suspensions were prepared by triturating the lecithin with hot $\mathrm{M} / 6 \mathrm{NaCl}$ solution $\left(80^{\circ} \mathrm{C.}\right)$.

The cholesterin which I employed was Menck's. Stable suspensions were prepared by triturating it with hot $\mathrm{M} / 100$ sodium oleate solution in $\mathrm{M} / 6 \mathrm{NaCl}$.

The lecithin was mixed with rabbit serum in two ways, namely by injecting $10 \mathrm{cc}$. of a $2 \%$ suspension directly into the circulation through the marginal vein of the ear of a large rabbit, and bleeding the animal from the carotid about 5 minutes later, and also by adding the suspension directly to normal rabbit serum. It was found impossible to inject the cholesterin suspension directly into the circulation, for thrombi were formed and the animals died before they could be bled. The blood was collected by bleeding animals from the carotid into sterile tubes, allowing the blood to clot, and pipetting off the clear serum.

Both the normal serum and that derived from the animal which had received lecithin intravenously were rendered isotonic with seawater by the addition of $10 \mathrm{cc}$. of $2 \frac{1}{2} \mathrm{M} \mathrm{NaCl}$ to $65 \mathrm{cc}$. of serum. The normal, isotonic serum was divided into three portions. The first was diluted to $1,1 / 2,1 / 4 \ldots 1 / 32$ by successive additions of filtered sea-water. To the second portion, measuring 7.5 ce., was added $3 / 10$ ce. of a $2 \%$ emulsion of lecithin and to a third, also measuring 7.5 cc., was added $3 / 10$ ce. of a $2 \%$ emulsion of cholesterin. These mixtures and the serum from the animal which had received lecithin intravenonsly were then diluted to $1,1 / 2,1 / 4 \ldots 1 / 32$ by successive additions of filtered sea-water.

The eggs from one female of Strongylocentrotus purpuratus were sensitised by four minutes immersion in $3 / 8 \mathrm{M} \mathrm{SrCl}_{2}$. To 2 cc. portions of each of the above sera and dilutions thereof were added 2 drops of an emulsion of the sensitised eggs, the serum being agitated gently as the eggs were dropped in. 
The following were the results obtained:

Percentage of membranes formed in 20 minutes.

\begin{tabular}{c|c|c|c|c}
\hline Dilution & $\begin{array}{c}\text { Normal serum } \\
\text { (rabbit) }\end{array}$ & $\begin{array}{c}\text { Serum from rabbit which } \\
\text { had received lecithin } \\
\text { intravenously }\end{array}$ & $\begin{array}{c}\text { Normal serum } \\
\text { + lecithin }\end{array}$ & $\begin{array}{c}\text { Normal serum } \\
\text { + cholesterin }\end{array}$ \\
\hline 1 & 100 & 100 & 100 & 100 \\
1,2 & 0 & 0 & 0 & 0 \\
$1 / 4$ & 0 & 0 & 0 & 0 \\
$1 / 8$ & 10 & 1 & 2 & 26 \\
$1 / 16$ & 02 & 16 & 40 & 32 \\
$1 / 32$ & 28 & 80 & 38 & 50
\end{tabular}

Percentage of membranes formed in $1 \frac{1 / 2}{2}$ hours.

\begin{tabular}{c|c|c|c|c}
\hline Dilution & $\begin{array}{c}\text { Normal serum } \\
\text { (rabbit) }\end{array}$ & $\begin{array}{c}\text { Serum from rabbit which } \\
\text { had receired lecithin } \\
\text { intravenously }\end{array}$ & $\begin{array}{c}\text { Normal serum } \\
\text { + lecithin }\end{array}$ & $\begin{array}{c}\text { Normal serum } \\
\text { +cholesterin }\end{array}$ \\
\hline 1 & 100 & 100 & 100 & 100 \\
$1 / 2$ & 0 & 0 & 0 & 0 \\
$1 / 4$ & 36 & 20 & 28 & 20 \\
$1 / 8$ & 50 & 56 & 44 & 44 \\
$1 / 16$ & 100 & 86 & 44 & 100 \\
$1 / 32$ & 50 & 100 & 84 & 100
\end{tabular}

Percentage cytolysed in $1 \frac{1 / 2}{2}$ hours.

\begin{tabular}{l|c|c|c|c}
\hline Dilution & $\begin{array}{c}\text { Normal serum } \\
\text { (rabbit) }\end{array}$ & $\begin{array}{c}\text { Serum from rabbit which } \\
\text { had received lecithin } \\
\text { intravenously }\end{array}$ & $\begin{array}{c}\text { Normal serum } \\
\text { + lecithin }\end{array}$ & $\begin{array}{c}\text { Normal serum } \\
\text { + cholesterin }\end{array}$ \\
\hline 1 & 0 & 0 & 0 & 0 \\
$1 / 2$ & 0 & 0 & 0 & 0 \\
$1 / 4$ & 0 & 0 & 0 & 0 \\
$1 / 8$ & 2 & 6 & 2 & 12 \\
$1 / 16$ & 34 & 44 & 32 & 44 \\
$1 / 32$ & 22 & 18 & 28 & 30
\end{tabular}

All of the sera failed to cause membrane-formation in unsensitised eggs from the same female, even after over an hour's immersion.

It is evident that the fertilising and cytolysing agent in bloodserum is not in any respect affected by the admixture of lecithin or cholesterin with the serum. From this we may conclude that it is highly improbable that the fertilising agent is a lipoid, since it is almost incredible that a lipoid should not be affected in its action by admixture with lecithin or cholesterin. 


\section{Summary.}

1) The purest preparation of the Oöcytin from ox-serum which has as yet been obtained yields the protein reactions. The active substance, therefore, either is a protein or peptone or else the method of preparation which is employed precipitates a protein or peptone along with it.

2) The amount of this substance which is obtainable from one litre of ox-serum lies between 10 and 40 milligrams.

3) Oöcytin is present in WrrTe's Peptone, hence it is either digested with difficulty or not at all by pepsin.

4) Oöcytin is not a lipoid.

\section{Zusammenfassung,}

1) Die reinste Präparation des 0öcytins aus Rindsserum, welche man bis jetzt erhalten konnte, zeigt noch die Proteinreaktionen. Die wirksame Substanz ist daber entweder ein Protein oder Pepton, oder die angewendete Prïparationsmethode schlägt zagleich mit ihr ein Protein oder Pepton nieder.

2) Die Menge dieser Substanz, welche man aus einem Liter Rindsserum erhalten kann, schwankt zwischen 10 und 40 Milligrammen.

3) Oöcytin ist in Wixtes Pepton vorhanden; aus ihm läßt es sich nur mit Schwierigkeit oder überhaupt nicht durch Pepsin verdauen.

4) Oöcytin ist kein Lipoid.

(Übersetzt von W. Gebhardt.) 